\title{
Large Animal Models of Heart Failure With Reduced Ejection Fraction (HFrEF)
}

\begin{abstract}
Andreas Spannbauer, Denise Traxler, Katrin Zlabinger, Alfred Gugerell, Johannes Winkler, Julia Mester-Tonczar, Dominika Lukovic, Claudia Müller, Martin Riesenhuber, Noemi Pavo and Mariann Gyöngyösi*
\end{abstract}

Division of Cardiology, Department of Internal Medicine II, Medical University of Vienna, Vienna, Austria

Heart failure with reduced ejection fraction (HFrEF) is defined by an ejection fraction (EF) below 40\%. Many distinct disease processes culminate in HFrEF, among them acute and chronic ischemia, pressure overload, volume overload, cytotoxic medication, and arrhythmia. To study these different etiologies the development of accurate animal models is vital. While small animal models are generally cheaper, allow for larger sample sizes and offer a greater variety of transgenic models, they have important limitations in the context of HFrEF research. Small mammals have much higher heart rates and distinct ion channels. They also have much higher basal metabolic rates and their physiology in many ways does not reflect that of humans. The size of their organs also puts practical constraints on experiments. Therefore, large animal models have been developed to accurately simulate human HFrEF. This review aims to give a short overview of the currently established large animal models of HFrEF. The main animal models discussed are dogs, pigs, and sheep. Furthermore, multiple approaches for modeling the different etiologies of HF are discussed, namely models of acute and chronic ischemia, pressure overload, volume overload as well as cytotoxic, and tachycardic pacing approaches.

Keywords: heart failure, heart failure with reduced ejection fraction, translational research, large animal models, porcine, ovine, canine, review

\section{INTRODUCTION}

Heart failure (HF) is a complex clinical entity with multiple different etiologies. The primary characteristic of $\mathrm{HF}$ is reduced contractile force or inadequate filling. The main causes are ischemic injury as well as pressure or volume overload. Globally, more than 26 million patients are affected, with prevalence reaching more than $12 \%$ above 70 years of age $(1,2)$. HF is further categorized into three subgroups; (1) HF with reduced ejection fraction (HFrEF) with an ejection fraction (EF) below 40\%; (2) HF with midrange $\mathrm{EF}$ (HFmrEF) with an EF of 40-50\%; (3) HF with preserved EF ( $\mathrm{HFpEF}$ ) with $\mathrm{EF}>50 \%$. The relative incidence of these three subgroups has been shifting in recent decades, toward declining HFrEF, and increasing HFpEF. According to a recent 30-year analysis of the Framingham Heart Study, newly diagnosed HF consists of 56.2\% HFpEF, 31.1\% HFrEF, and $12.8 \%$ HFmrEF (3). This shift is due to improvements in the management of acute myocardial infarction and better management of atherosclerotic risk factors, such as hyperlipidemia. However, it is important to note that while the relative proportion of HFrEF is decreasing, the absolute number of HFrEF patients is projected to increase over the coming decades. 


\section{Importance of Large Animal Models of HFrEF}

Animal models in general have been a cornerstone of basic and translational research. Among available models of human diseases, small mammals like mice, and rats are used in the vast majority. Their advantages include relatively low cost, and space requirements, which enable larger sample sizes, availability of many transgenic models, and short life-cycles, which allow the modeling of disease over an entire lifespan.

In comparison, large animal models are more labor-intensive, costly and they require larger, and more specialized facilities. Due to longer generation times, very few transgenic models exist, and new ones are difficult to establish. However, they have several significant advantages that make them an absolute necessity in basic and translational research.

There are several physiological differences between small mammals and humans that are relevant for cardiovascular research. Prominent examples are much faster heart rates in mice (300-840 beats per $\min$ ) and rats (330-480 beats per $\mathrm{min})$, along with drastically different action potential durations, a different basal metabolic rate, and oxygen consumption as well as phenotypic differences in their stem cells (4). Therefore, extrapolation of data from small animal models to humans is difficult. This is best showcased by a long list of therapies and molecular targets that seemed promising in rodents but then failed to be replicated in large mammals and humans.

Another practical limitation of small animal models is the size of their organs. The resolution at which spatial relationships like the spread of electrical potentials can be analyzed is severely constrained. This is especially relevant in the context of HFrEF, which is associated with many different forms of atrial and ventricular arrhythmias. It also makes a direct translation of interventional and surgical procedures into clinical practice impossible. Large animal models are therefore an important step toward accurately simulating human diseases and they have been and will continue to be invaluable in cardiovascular research.

There is an ongoing debate on which large animal model most closely resembles human cardiovascular physiology $(5,6)$. Historically, canines (dogs) were the preferred model organism, and many of the early landmark studies in heart disease, especially those concerning myocardial ischemia and arrhythmia, were conducted using this model $(7,8)$. An important drawback of the canine model is an extensive preformed epicardial collateral circulation, which can have a variable effect on infarct size.

The use of canine models has decreased over time, in part also due to cultural values. Animal experiments on dogs are often viewed unfavorably by the public when compared to other animal species. In some countries this has led to tougher regulations on canine experiments, which can constrain the study design and increase cost (9).

In recent decades, porcine (pig) models have become very popular for cardiovascular research. Their physiology, heart size, immune system and anatomy closely resemble that of humans and their coronaries have very little collateral circulation. It has been argued that in terms of coronary circulation, the pig heart therefore more closely resembles a "young heart," while the dog heart with its extensive collaterals more closely resembles an "old heart" which has developed collaterals in response to chronic ischemic disease. However, this argument only extends to vascular anatomy and obviously not to the extensive remodeling that otherwise occurs in a human heart suffering from chronic ischemic disease.

A very important drawback of the pig model, is a high rate of sudden death due to tachyarrhythmias. A common approach to keep mortality at acceptable levels is the use of aggressive airway management, antiarrhythmic drugs and if necessary, defibrillation.

The ovine (sheep) model has many of the same attributes previously mentioned for pigs. There has been little effort to directly compare one against the other and they are both considered equally valid models. Other species that are rarely used include bovine (cow) and goat models.

This review aims to give a short overview of the currently established large animal models of HFrEF. A short summary of the different models, their advantages and disadvantages as well as all references used in the main text are listed in Table 1. The literature on this topic is vast so we cite a few illustrative examples of each model, and refer them in Table 1. Figure 1 summarizes the pros and cons of surgical vs. endovascular models in general and briefly lists the different models.

\section{MYOCARDIAL ISCHEMIC MODELS OF HFrEF}

\section{Models of Acute Myocardial Ischemia}

In essence, large animal models of acute ischemia seek to induce or simulate acute myocardial infarction (AMI), which is a sudden and extensive ischemic injury, usually through total occlusion of a coronary artery. The most straightforward models use intracoronary injections of thrombogenic material to permanently occlude a coronary artery. Commonly used materials include microbeads, collagen, gelatin, coils or autologous platelet aggregates (10-15). These models have the advantage of being fairly easy to carry out and of simulating the thrombotic nature of AMI, but they offer less precise control of infarct size than other methods. Additionally, they do not reflect the typical clinical setting in which AMI patients undergo percutaneous coronary intervention (PCI) and subsequent revascularization. Therefore, this model is most appropriate in studying the general mechanisms of acute myocardial ischemia and the subset of AMI with no subsequent revascularization.

In ischemia/reperfusion (I/R) models, ischemia is induced by either endovascular occlusion (e.g., balloon inflation) or surgical ligation of a coronary artery $(16,17,19,20,28)$. After a set amount of time, the artery is re-opened, leading to reperfusion. Endovascular (percutaneous) approaches have the benefit of having lower peri- and post-interventional complication rates and of being most similar to the clinical setting, while surgical approaches allow for the implantation of additional equipment, for instance radio-opaque markers used by Mukherjee et al. to monitor infarct expansion over time (18). The percutaneous $\mathrm{I} / \mathrm{R}$ model is especially relevant because it closely models the 
TABLE 1 | Overview of large animal models of HFrEF.

\begin{tabular}{|c|c|c|c|c|}
\hline Type & Method & Advantages & Disadvantages & Literature \\
\hline \multirow[t]{3}{*}{ Acute ischemia } & Embolization & Low-complexity, cheap & $\begin{array}{l}\text { Less reproducible, less precise, no } \\
\text { reperfusion possible }\end{array}$ & $\begin{array}{l}\text { Canine }(10) \\
\text { Porcine }(11-13) \\
\text { Ovine }(14,15)\end{array}$ \\
\hline & LAD ligation & $\begin{array}{l}\text { Reproducible, possibility of reperfusion, } \\
\text { extra-coronary device implantation } \\
\text { possible }\end{array}$ & $\begin{array}{l}\text { Open-chest, lethal arrhythmias, } \\
\text { surgical complications, labor } \\
\text { intensive, }\end{array}$ & $\begin{array}{l}\text { Canine }(16) \\
\text { Porcine }(17,18) \\
\text { Ovine }(19,20)\end{array}$ \\
\hline & Balloon occlusion & $\begin{array}{l}\text { Reproducible, possibility of reperfusion, } \\
\text { closed-chest, fewer complications }\end{array}$ & Less precise than surgical ligation & $\begin{array}{l}\text { Canine }(21) \\
\text { Porcine }(22-27) \\
\text { Ovine }(28)\end{array}$ \\
\hline \multirow[t]{2}{*}{ Chronic ischemia } & $\begin{array}{l}\text { Repeated } \\
\text { microembolization }\end{array}$ & Good model of microvascular disease & Repeat interventions, labor intensive & $\begin{array}{l}\text { Canine }(29,30) \\
\text { Ovine }(31,32) \\
\text { Bovine }(33)\end{array}$ \\
\hline & $\begin{array}{l}\text { Ameroid constrictor, bottleneck } \\
\text { stent, copper-plated stent }\end{array}$ & Good model of single vessel disease & $\begin{array}{l}\text { Variable degree of stenosis and } \\
\text { LVEF reduction }\end{array}$ & $\begin{array}{l}\text { Canine (34) } \\
\text { Porcine (35-42) } \\
\text { Ovine (43) }\end{array}$ \\
\hline \multirow[t]{4}{*}{ Pressure overload } & Surgical aortic banding & $\begin{array}{l}\text { Reproducible, minimal surgical } \\
\text { procedure }\end{array}$ & Abrupt increase in pressure & $\begin{array}{l}\text { Canine }(44) \\
\text { Porcine }(45,46) \\
\text { Ovine }(47)\end{array}$ \\
\hline & Stenting of descending aorta & $\begin{array}{l}\text { Good model of aortic stenosis, gradual } \\
\text { pressure overload, very similar to human } \\
\text { conditions }\end{array}$ & $\begin{array}{l}\text { Long time is necessary to develop } \\
\text { left ventricular hypertrophy and } \\
\text { dilation }\end{array}$ & Porcine (48) \\
\hline & Renal artery stenosis & $\begin{array}{l}\text { Good model of severe systemic } \\
\text { hypertension, low-complexity, single } \\
\text { intervention }\end{array}$ & $\begin{array}{l}\text { Hormonal dysregulation, difficult to } \\
\text { control }\end{array}$ & $\begin{array}{l}\text { Canine }(49,50) \\
\text { Porcine }(51) \\
\text { Ovine }(52)\end{array}$ \\
\hline & $\begin{array}{l}\text { DOCA pellet S.C. implantation } \\
\text { with high salt diet }\end{array}$ & Simple non-invasive method & $\begin{array}{l}\text { Mild systemic hypertension, } \\
\text { uncertain effect on left ventricular } \\
\text { function }\end{array}$ & Porcine (53) \\
\hline \multirow[t]{2}{*}{ Volume overload } & Mitral regurgitation & $\begin{array}{l}\text { Good model of volume overload, } \\
\text { reproducible }\end{array}$ & Technically difficult & $\begin{array}{l}\text { Canine }(54-57) \\
\text { Porcine }(58) \\
\text { Ovine }(59)\end{array}$ \\
\hline & Arteriovenous fistula & & $\begin{array}{l}\text { Low clinical relevance, not } \\
\text { well-established in large animals }\end{array}$ & $\begin{array}{l}\text { Goat (60) } \\
\text { Ovine (61) }\end{array}$ \\
\hline Cytotoxic & Anthracyclines & $\begin{array}{l}\text { Good model of doxorubicin-induced } \\
\text { heart failure, simple non-invasive method }\end{array}$ & $\begin{array}{l}\text { Narrow clinical relevance, toxic } \\
\text { substances, often only in } \\
\text { combination with other methods }\end{array}$ & $\begin{array}{l}\text { Canine }(62,63) \\
\text { Porcine }(64) \\
\text { Ovine }(65), \\
\text { Goat }(60)\end{array}$ \\
\hline Pacing & Rapid pacing & Good model of tachycardic remodeling & $\begin{array}{l}\text { Reversible HF, qualitatively different } \\
\text { remodeling }\end{array}$ & $\begin{array}{l}\text { Canine }(66,67) \\
\text { Porcine }(68-72) \\
\text { Ovine }(73)\end{array}$ \\
\hline
\end{tabular}

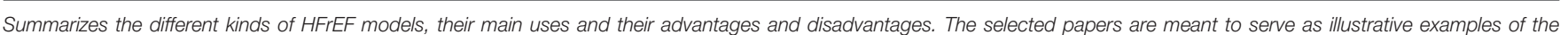

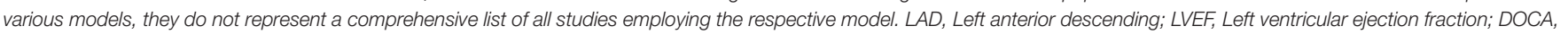
deoxycorticosterone acetate; sc, subcutaneous; HF, Heart Failure.

common clinical scenario of ST-elevation myocardial infarction, in which a prolonged period of ischemia is followed by revascularization through PCI (21-27).

\section{Chronic Myocardial Ischemia Models}

HFrEF can also develop gradually as a consequence of progressive coronary artery disease and microvascular occlusions. A common approach to model this etiology is the use of repeated microembolizations, often using microspheres (29-33). Standard protocols often use weekly injections of microspheres between 40 and $100 \mu \mathrm{m}$ until a desired EF is reached (31). While this method offers a gradual decline in left ventricular function with a lower mortality rate than acute models of ischemia, it is also very labor intensive, and puts more strain on the animals, since multiple interventions are necessary within a short period of time.

Another possibility is the use of implanted devices that gradually constrict a coronary artery. A surgical option is the ameroid constrictor, which is wrapped around a coronary artery, and expands gradually as it absorbs water $(34-37,43)$. This is also often combined with ligating a distal part of the coronary artery.

Using an endovascular approach there are multiple options to induce chronic occlusion. For example, Von Degenfeld et al. used a ligature in the middle of a bare-metal stent prior to implantation to induce an hourglass-shaped stenosis after deployment (38). In a similar fashion, Rissanen et al. used heatshrink PTFE tubes to deform the distal end of their stent to 


\section{Large Animal Models of HFrEF}

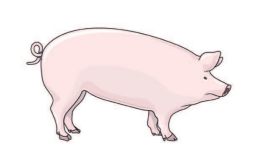

Surgical Models

Pro: - Very precise

- More variation between procedures

- Implantation of extra

monitoring equipment

Con: - High labor intensity

- Slow

- More post-OP complications

- More strain on animals

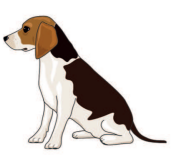

.

\section{Endovascular Models}

Pro: - Lower labor intensity

- Faster (allows for higher volume)

- Lower peri- / post-OP complications

- Less strain on animals

Con: - Limited devices / methodologies

- Imaging required

- No implantation of extra equipment

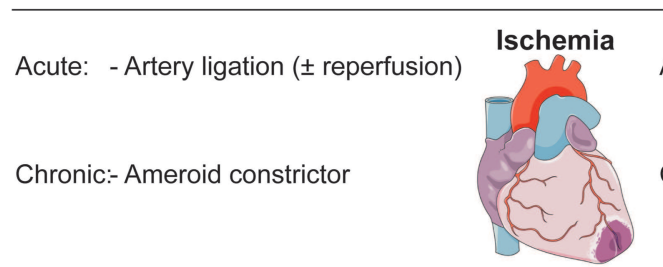
Acute: - Balloon occlusion ( \pm reperfusion)
- Embolization

Chronic:- Repeat microembolization - Bottleneck/Hourglass stent - Copper-plated stent

- Aortic banding / cuffing
- Banding of A. renalis
- s.c. DOCA pellets (+diet)
- Surgical mitral regurgitation
- Arteriovenous fistula (AVF)
- Doxorubicin (i.v.) + AVF

FIGURE 1 | Graphical summary of large animal models of HFrEF, divided into surgical and endovascular methods. Images were obtained from https://smart.servier. com and are available under a creative commons license.

create a bottleneck shape and immediately reduce blood flow (39). These methods create an empty space between implanted devices and the vessel wall. In this space, thrombus builds up and gradually constricts the vessel, while under dual anti-platelet therapy (DAPT), the lumen remains open. Varying DAPT dosage, the time-point of total occlusion of the vessel can be varied between 1-4 weeks. These models have the benefit of requiring only a single, short and low complexity intervention, 
however the acute mortality rate can be high with up to $37 \%$ in pigs (39). Others have relied on neointimal hyperplasia following implantation of copper-plated stents $(40,41)$ or polymer-coated stents (42). In these models, the development of hemodynamically significant stenosis usually takes 3-6 weeks. However, the degree of stenosis and the mortality rate differ greatly between the studies. Ultimately, the choice of model depends on the preferred time course of the stenosis, acceptable mortality rates and expertise, as all of these methods require experience to give reproducible results.

\section{PRESSURE OVERLOAD MODELS OF HFrEF}

Despite the fact that pressure-overload induced ventricular dysfunction secondary to either aortic stenosis or hypertension are very common clinical entities, few large animal models exist. In pressure overload, a gradual increase in afterload results in compensatory left ventricular (LV) hypertrophy, fibrosis and diastolic dysfunction (i.e., reduced compliance). These compensatory mechanisms eventually give way to decompensation and LV dilatation. Surgical models usually rely on surgical banding of the ascending or descending aorta (4447). These models can vary in their approach in that some rely on producing an immediate aortic stenosis, others use a gradually inflating cuff, while implanting devices in young animals the aortic stenosis develops gradually, as the animals grow. Since aortic valve stenosis in humans develops slowly, models that induce an increasing degree of stenosis over time are likely more accurate in simulating HFrEF secondary to aortic stenosis.

A recent endovascular model for gradual development of pressure overload involves stenting of the descending aorta of young pigs. The intraluminal diameter of the stent stays constant while the pigs grow, leading to gradual aortic stenosis, LV hypertrophy and fibrosis (48).

Other models have aimed to simulate systemic hypertension. Important examples are induction of renal artery stenosis (49, 50), which is most established in dogs but has also been used in pig and sheep $(51,52)$. An interesting porcine model is the subcutaneous implantation of deoxycorticosterone acetate (DOCA) pellets, an aldosterone analog, combined with a highsalt diet, inducing systemic hypertension over time (53).

\section{VOLUME OVERLOAD MODELS OF HFrEF}

The most common clinical causes for volume-overload-inducedHFrEF are aortic and mitral regurgitation. Aortic regurgitation, however, is difficult to induce experimentally in a reproducible fashion, therefore most animal models have focused on inducing mitral regurgitation (54-59). Typically, a catheter-based intervention is used in which the mitral chordae are cut. This technique has been successfully used in dogs, pigs and sheep.

While the creation of arteriovenous fistulas is a common volume overload model in small animals, it is rarely used in large animal models and usually only in combination with other methods $(60,61)$.

\section{CYTOTOXIC MODELS OF HFrEF}

Cytotoxic HFrEF is a disease entity with growing clinical importance, and is most frequently encountered after chemotherapy with anthracyclines (74). Consequently, only few cytotoxic models of HFrEF exist, most of them using anthracyclines in combination with a surgically created arteriovenous fistula to induce heart failure. Tessier et al. administered 1-2 $\mathrm{mg} / \mathrm{kg}$ of doxorubicin intravenously $2 \mathrm{x} /$ week for 13 weeks in goats, whereas Toyoda et al. used weekly intracoronary infusions of $0.7 \mathrm{mg} / \mathrm{kg}$ of doxorubicin over 5 weeks in canines $(60,62-65)$, while our group has administered doxorubicin and its derivatives in human doses in pigs (under publication).

\section{PACING MODELS OF HFrEF}

Another reliable method to induce heart failure of varying degrees is tachycardic pacing. In this method, a pacemaker is used to induce tachycardia of typically between $180-240 \mathrm{bpm}$. This leads to biventricular dilatation, increased wedge pressure and an increase in systemic vascular resistance within 2 to 3 weeks (66). Different iterations of this model vary in their placement of the pacing wires in the atria or ventricles, with some even placing multiple leads to test various stimulation patterns $(66-69,73)$. Tachycardic pacing has been successfully used in canine, porcine, and ovine models (70-72). This model is particularly useful in studying HFrEF secondary to prolonged tachycardia. The HFrEF resulting from tachycardic pacing also differs from the other described models in some important respects. While in typical HFrEF, the reduction in left ventricular function is accompanied by changes in LV mass and fibrosis, this is not the case for pacinginduced HFrEF $(70,71)$. It is thought that prolonged tachycardic pacing leads to an intrinsic loss of myocardial contractility, which is further supported by the observation that contractile reserve in response to inotropic drugs is severely reduced (75). This reduction in contractility is reversible after the end of tachycardic pacing, with an often complete normalization of heart function within days or weeks (67).

\section{CONCLUSION}

The choice of an appropriate animal model is the foundation of any successful translational research endeavor. Large animal models more accurately reflect human physiology and anatomy and are therefore invaluable in generating and translating basic research insights into clinical practice.

Here we have outlined the established large animal models for HFrEF categorized by which mechanism of HFrEF development is being modeled. This being a mini-review, an in-depth analysis of the various models are described in other reviews (76-78).

Ultimately, the choice, of which model is the most appropriate, is determined by the specific research question. The main three species discussed here, namely canine, porcine and ovine are all considered equally valid for most HFrEF related research questions and practical concerns like 
experience, available facilities, funding, and local regulations are often the main determinants in choosing one over the other.

Animal models have steadily been gaining in sophistication over time, but there is no single model or methodology that can accurately reflect the entire complex reality of HFrEF observed in human patients. This is especially true regarding the chronic nature of HFrEF and the numerous comorbidities that often afflict elderly HFrEF patients. Another level of complexity is added when medications are considered. While many models do include necessary medications like anti-platelet therapy or anti-arrhythmic drugs to ensure the survival of the animals, there is no consensus on whether they should also receive

\section{REFERENCES}

1. Savarese G, Lund LH. Global public health burden of heart failure. Cardiac Fail Rev. (2017) 3:7-11. doi: 10.15420/cfr.2016:25:2

2. Ponikowski P, Anker SD, AlHabib KF, Cowie MR, Force TL, Hu S, et al. Heart failure: preventing disease and death worldwide. ESC Heart Fail. (2014) 1:4-25. doi: 10.1002/ehf2.12005

3. Vasan RS, Xanthakis V, Lyass A, Andersson C, Tsao C, Cheng S, et al. Epidemiology of left ventricular systolic dysfunction and heart failure in the framingham study. an echocardiographic study over 3 decades. (2018) 11:1-11. doi: 10.1016/j.jcmg.2017.08.007

4. Ginis I, Luo Y, Miura T, Thies S, Brandenberger R, Gerecht-Nir S, et al. Differences between human and mouse embryonic stem cells. Dev Biol. (2004) 269:360-80. doi: 10.1016/j.ydbio.2003.12.034

5. Milani-Nejad N, P.Janssen ML. Small and large animal models in cardiac contraction research: advantages and disadvantages. Pharmacol. Ther. (2014) 141:235-49. doi: 10.1016/j.pharmthera.2013.10.007

6. Janetzki S, Britten CM.Gallegos RP, Rivard AL, Bianco RW. Animal models for cardiac research. In: Iaizzo PA, editor, Handbook of CARDIAC Anatomy, Physiology, and Devices Totowa, NJ: Humana Press (2005). p. 287-301.

7. Reimer KA, Jennings RB. The "wavefront phenomenon" of myocardial ischemic cell death. II. Transmural progression of necrosis within the framework of ischemic bed size (myocardium at risk) and collateral flow. Lab Invest. (1979) 40:633-44.

8. Reimer KA, Lowe JE, Rasmussen MM, Jennings RB. The wavefront phenomenon of ischemic cell death. 1. myocardial infarct size vs duration of coronary occlusion in dogs. Circulation. (1977) 56:786-94. doi: 10.1161/01.CIR.56.5.786

9. Hasiwa N, Bailey J, Clausing P, Daneshian M, Eileraas M, Farkas S, et al. Critical evaluation of the use of dogs in biomedical research and testing in Europe. Altex. (2011) 28:326-40. doi: 10.14573/altex.2011.4.326

10. Herr MD, McInerney JJ, Copenhaver GL, Morris DL. Coronary artery embolization in closed-chest canines using flexible radiopaque plugs. J Appl Physiol (1985). 64:2236-9. doi: 10.1152/jappl.1988.64. 5.2236

11. Moller-Helgestad OK, Ravn HB, Moller JE. Large porcine model of profound acute ischemic cardiogenic shock. Methods Mol Biol. (2018) 1816:343-52. doi: 10.1007/978-1-4939-8597-5_27

12. Hegyi B, Bossuyt J, Griffiths LG, Shimkunas R, Coulibaly Z, Jian $Z$, et al. Complex electrophysiological remodeling in postinfarction ischemic heart failure. Proc Natl Acad Sci USA. (2018) 115:E3036-44. doi: 10.1073/pnas.1718211115

13. Sakaguchi G, Sakakibara Y, Tambara K, Lu F, Premaratne G, Nishimura $\mathrm{K}$, et al. A pig model of chronic heart failure by intracoronary embolization with gelatin sponge. Ann Thorac Surg. (2003) 75:1942-7. doi: 10.1016/S0003-4975(03)00184-X

14. Kwiatkowski P, Sai-Sudhakar C, Philips A, Parthasarathy S, Sun B. Development of a novel large animal model of ischemic heart failure standard heart failure medications that would better reflect the clinical setting.

Nevertheless, the wide variety of large animal models presented here are the best approximations to human HFrEF that are currently available and they will surely continue to improve our understanding and thereby help improve patient outcomes.

\section{AUTHOR CONTRIBUTIONS}

AS wrote the main body of the manuscript. DT, DL, KZ, JM-T, MR, NP, and CM helped with literature research and gave feedback regarding style. AG, JW, and MG helped structure and revise the manuscript. using autologous platelet aggregates. Int J Artif Organs. (2010) 33:63-71. doi: 10.1177/039139881003300201

15. Chandrakala AN, Kwiatkowski P, Sai-Sudhakar CB, Sun B, Phillips A, Parthasarathy S. Induction of early biomarkers in a thrombus-induced sheep model of ischemic heart failure. Tex Heart Inst J. (2013) 40:511-20.

16. Jugdutt BI, Menon V. Valsartan-induced cardioprotection involves angiotensin II type 2 receptor upregulation in dog and rat models of in vivo reperfused myocardial infarction. J Card Fail. (2004) 10:74-82. doi: 10.1016/S1071-9164(03)00584-0

17. Munz MR, Faria MA, Monteiro JR, Aguas AP, Amorim MJ. Surgical porcine myocardial infarction model through permanent coronary occlusion. Compar Med. (2011) 61:445-452.

18. Mukherjee R, Brinsa TA, Dowdy KB, Scott AA, Baskin JM, Deschamps AM, et al. Myocardial infarct expansion and matrix metalloproteinase inhibition. Circulation. (2003) 107:618-25. doi: 10.1161/01.CIR.0000046449.36178.00

19. Moainie SL, Gorman JH, Guy TS, Bowen FW, Jackson BM, Plappert T, et al. An ovine model of postinfarction dilated cardiomyopathy. Ann Thorac Surg. (2002) 74:753-60. doi: 10.1016/S0003-4975(02)03827-4

20. Pilla JJ, Blom AS, Brockman DJ, Ferrari VA, Yuan Q, Acker MA. Passive ventricular constraint to improve left ventricular function and mechanics in an ovine model of heart failure secondary to acute myocardial infarction. J Thoracic Cardiovas Surgery. (2003) 126:1467-75. doi: 10.1016/S0022-5223(03)00739-6

21. Cohen MV, Eldh P. Experimental myocardial infarction in the closed-chest dog: controlled production of large or small areas of necrosis. Am Heart J. (1973) 86:798-804. doi: 10.1016/0002-8703(73)90283-4

22. van der Spoel TI, Jansen of Lorkeers SJ, Agostoni P, van Belle E, Gyöngyösi M, Sluijter JP, et al. Human relevance of pre-clinical studies in stem cell therapy: systematic review and meta-analysis of large animal models of ischaemic heart disease. Cardiovasc Res. (2011) 91:649-58. doi: 10.1093/cvr/cvr113

23. Pavo N, Lukovic D, Zlabinger K, Zimba A, Lorant D, Goliasch G, et al. Sequential activation of different pathway networks in ischemia-affected and non-affected myocardium, inducing intrinsic remote conditioning to prevent left ventricular remodeling. Sci Rep. (2017) 7:43958. doi: 10.1038/srep43958

24. Emmert MY, Wolint P, Jakab A, Sheehy SP, Pasqualini FS, Nguyen TDL, et al. Safety and efficacy of cardiopoietic stem cells in the treatment of postinfarction left-ventricular dysfunction - from cardioprotection to functional repair in a translational pig infarction model. Biomaterials. (2017) 122:48-62. doi: 10.1016/j.biomaterials.2016.11.029

25. Ishikawa K, Aguero J, Tilemann L, Ladage D, Hammoudi N, Kawase Y, et al. Characterizing preclinical models of ischemic heart failure: differences between LAD and LCx infarctions. Am J Physiol. (2014) 307:H1478-86. doi: 10.1152/ajpheart.00797.2013

26. Spannbauer A, Traxler D, Lukovic D, Zlabinger K, Winkler J, Gugerell A, et al. Effect of ischemic preconditioning and postconditioning on exosome-rich fraction microrna levels, in relation with electrophysiological parameters and ventricular arrhythmia in experimental closed-chest reperfused myocardial infarction. Int J Mol Sci. (2019) 20:E2140. doi: 10.3390/ijms20092140 
27. Weber C, Neacsu I, Krautz B, Schlegel P, Sauer S, Raake P, et al. Therapeutic safety of high myocardial expression levels of the molecular inotrope S100A1 in a preclinical heart failure model. Gene Ther. (2014) 21:131-8. doi: 10.1038 /gt.2013.63

28. Charles CJ, Elliott JM, Nicholls MG, Rademaker MT, Richards M. Myocardial infarction with and without reperfusion in sheep: early cardiac and neurohumoral changes. Clin Sci. (2000) 98:703-11. doi: 10.1042/cs0980703

29. Sabbah HN, Stein PD, Kono T, Gheorghiade M, Levine TB, Jafri S, et al. A canine model of chronic heart failure produced by multiple sequential coronary microembolizations. Am J Physiol. (1991) 260(Pt 2):H1379-84. doi: 10.1152/ajpheart.1991.260.4.H1379

30. Morita H, Khanal S, Rastogi S, Suzuki G, Imai M, Todor A, et al. Selective matrix metalloproteinase inhibition attenuates progression of left ventricular dysfunction and remodeling in dogs with chronic heart failure. Am J Physiol Heart Circ Physiol. (2006) 290:H2522-7. doi: 10.1152/ajpheart.00932.2005

31. Monreal G, Gerhardt MA, Kambara A, Abrishamchian AR, Bauer JA, Goldstein AH. Selective microembolization of the circumflex coronary artery in an ovine model: dilated, ischemic cardiomyopathy and left ventricular dysfunction. J Card Fail. (2004) 10:174-83. doi: 10.1016/j.cardfail.2003.08.013

32. Schmitto JD, Ortmann P, Wachter R, Hintze E, Popov AF, Kolat P, et al. Chronic heart failure induced by multiple sequential coronary microembolization in sheep. Int J Artif Organs. (2008) 31:348-53. doi: $10.1177 / 039139880803100412$

33. Sherwood LC, Sobieski MA, Koenig SC, Giridharan GA, Slaughter MS. Benefits of aggressive medical management in a bovine model of chronic ischemic heart failure. ASAIO J. (2013) 59:221-9. doi: 10.1097/MAT.0b013e3182894e66

34. Heusch G, Guth BD, Seitelberger R, Ross J. Attenuation of exercise-induced myocardial ischemia in dogs with recruitment of coronary vasodilator reserve by nifedipine. Circulation. (1987) 75:482-90. doi: 10.1161/01.CIR.75.2.482

35. Tarkia M, Stark C, Haavisto $M$, Kentala R, Vähäsilta $T$, Savunen $T$, et al. Cardiac remodeling in a new pig model of chronic heart failure: assessment of left ventricular functional, metabolic, and structural changes using PET, CT, and echocardiography. J Nucl Cardiol. (2015) 22:655-65. doi: 10.1007/s12350-015-0068-9

36. Teramoto N, Koshino K, Yokoyama I, Miyagawa S, Zeniya T, Hirano Y, et al. Experimental pig model of old myocardial infarction with long survival leading to chronic left ventricular dysfunction and remodeling as evaluated by PET. J Nucl Med. (2011) 52:761-8. doi: 10.2967/jnumed.110. 084848

37. Milla JM, Galan-Arriola C, Gonzalez ML, Carnero M, Cobiella FJ, Castro JM, et al. Characterization by multimodality imaging of a large animal model of ischemic dilated cardiomyopathy with translational implications. $J$ Am College Cardiol. (2019) 73(9 Suppl 1):759. doi: 10.1016/S0735-1097(19)3 1367-1

38. von Degenfeld G, Raake P, Kupatt C, Lebherz C, Hinkel R, Gildehaus FJ, et al. Selective pressure-regulated retroinfusion of fibroblast growth factor- 2 into the coronary vein enhances regional myocardial blood flow and function in pigs with chronic myocardial ischemia. J Am College Cardiol. (2003) 42:1120-8. doi: 10.1016/S0735-1097(03)00915-X

39. Rissanen TT, Nurro J, Halonen PJ, Tarkia M, Saraste A, Rannankari M, et al. The bottleneck stent model for chronic myocardial ischemia and heart failure in pigs. Am J Physiol Heart Circ Physiol. (2013) 305:H1297-308. doi: 10.1152/ajpheart.00561.2013

40. Wu M, Bogaert J, D’hooge J, Sipido K, Maes F, Dymarkowski S, et al. Closedchest animal model of chronic coronary artery stenosis. assessment with magnetic resonance imaging. Int J Cardiovasc Imaging. (2010) 26:299-308. doi: 10.1007/s10554-009-9551-1

41. Song W, Lee J, Kim H, Shin J, Oh D, Tio F, et al. A new percutaneous porcine coronary model of chronic total occlusion. J Invasive Cardiol. (2005) 17:452-4.

42. Horstick G, Bierbach B, Abegunewardene N, Both S, Kuhn S, Manefeld D, et al. Critical single proximal left arterial descending coronary artery stenosis to mimic chronic myocardial ischemia: a new model induced by minimal invasive technology. J Vasc Res. (2009) 46:290-8. doi: 10.1159/000181545

43. Chekanov V, Akhtar M, Tchekanov G, Dangas G, Shehzad MZ, Tio F, et al. Transplantation of autologous endothelial cells induces angiogenesis. Pacing Clin Electrophysiol. (2003) 26(1p2):496-9. doi: 10.1046/j.1460-9592.2003.00080.x
44. Chien SF, Diana JN, Brum JM, Bove AA. A simple technique for producing supravalvular aortic stenosis in animals. Cardiovasc Res. (1988) 22:739-45. doi: $10.1093 / \mathrm{cvr} / 22.10 .739$

45. Bikou O, Miyashita S, Ishikawa K. Pig model of increased cardiac afterload induced by ascending aortic banding. Methods Mol Biol. (2018) 1816:337-42. doi: 10.1007/978-1-4939-8597-5_26

46. Ye Y, Gong G, Ochiai K, Liu J, Zhang J. High-energy phosphate metabolism and creatine kinase in failing hearts: a new porcine model. Circulation. (2001) 103:1570-6. doi: 10.1161/01.CIR.103.11.1570

47. Walther T, Schubert A, Falk V, Binner C, Walther C, Doll N, et al. Left ventricular reverse remodeling after surgical therapy for aortic stenosis: correlation to renin-angiotensin system gene expression. Circulation. (2002). 106(12 Suppl 1):I23-6.

48. Gyöngyösi M, Pavo N, Lukovic D, Zlabinger K, Spannbauer A, Traxler D, et al. Porcine model of progressive cardiac hypertrophy and fibrosis with secondary postcapillary pulmonary hypertension. J Transl Med. (2017) 15:202. doi: 10.1186/s12967-017-1299-0

49. Nguyen TN, Chagas AC, Glantz SA. Left ventricular adaptation to gradual renovascular hypertension in dogs. Am J Physiol. (1993) 265(1 Pt 2):H22-38. doi: 10.1152/ajpheart.1993.265.1.H22

50. Munagala VK, Hart CY, Burnett JC, Meyer DM, Redfield MM. Ventricular structure and function in aged dogs with renal hypertension: a model of experimental diastolic heart failure. Circulation. (2005) 111:1128-35. doi: 10.1161/01.CIR.0000157183.21404.63

51. Urbieta-Caceres VH, Zhu XY, Gibson ME, Favreau FD, Jordan K, Lerman A, et al. Reversal of experimental renovascular hypertension restores coronary microvascular function and architecture. Am J Hypertension. (2011) 24:45865. doi: 10.1038/ajh.2010.259

52. Ramchandra R, McBryde F, George B, Paton JF, Mahesh D. Altered regulation of cardiac sympathetic nerve activity during hypertension. FASEB J. (2017) 31(1_suppl):1071.4.

53. Schwarzl M, Hamdani N, Seiler S, Alogna A, Manninger M, Reilly S, et al. A porcine model of hypertensive cardiomyopathy: implications for heart failure with preserved ejection fraction. Am J Physiol Heart Circ Physiol. (2015) 309:H1407-18. doi: 10.1152/ajpheart.00542.2015

54. Kleaveland JP, Kussmaul WG, Vinciguerra T, Diters R, Carabello BA. Volume overload hypertrophy in a closed-chest model of mitral regurgitation. Am J Physiol. (1988) 254(6 Pt 2):H1034-41. doi: 10.1152/ajpheart.1988.254.6.H1034

55. Spinale FG, Ishihra K, Zile M, DeFryte G, Crawford FA, Carabello BA. Structural basis for changes in left ventricular function and geometry because of chronic mitral regurgitation and after correction of volume overload. $J$ Thorac Cardiovasc Surg. (1993) 106:1147-57.

56. Carabello BA, Nakano K, Corin W, Biederman R, Spann JF. Left ventricular function in experimental volume overload hypertrophy. Am J Physiol. (1989) 256(4 Pt 2):H974-81. doi: 10.1152/ajpheart.1989.256.4.H974

57. Tsutsui H, Spinale FG, Nagatsu M, Schmid PG, Ishihara K, DeFreyte G, et al. Effects of chronic beta-adrenergic blockade on the left ventricular and cardiocyte abnormalities of chronic canine mitral regurgitation. J Clin Invest. (1994) 93:2639-48. doi: 10.1172/JCI117277

58. Watanabe S, Fish K, Bonnet G, Santos-Gallego CG, Leonardson L, Hajjar RJ, et al. Echocardiographic and hemodynamic assessment for predicting early clinical events in severe acute mitral regurgitation. Int J Cardiovasc Imaging. (2018) 34:171-5. doi: 10.1007/s10554-017-1215-y

59. Walther T, Schubert A, Falk V, Binner C, Kanev A, Bleiziffer S, et al. Regression of left ventricular hypertrophy after surgical therapy for aortic stenosis is associated with changes in extracellular matrix gene expression. Circulation. (2001) 104(12 Suppl 1):I54-8. doi: 10.1161/hc37t1.094777

60. Tessier D, Lajos P, Braunberger E, Pouchelon JL, Carpentier A, Chachques JC, et al. Induction of chronic cardiac insufficiency by arteriovenous fistula and doxorubicin administration. J Card Surg. (2003) 18:307-11. doi: 10.1046/j.1540-8191.2003.02044.x

61. Chekanov VS. A stable model of chronic bilateral ventricular insufficiency (dilated cardiomyopathy) induced by arteriovenous anastomosis and doxorubicin administration in sheep. J Thorac Cardiovasc Surg. (1999) 117:198-9. doi: 10.1016/S0022-5223(99)70494-0

62. Magovern JA, Christlieb IY, Badylak SF, Lantz GC, Kao RL. A model of left ventricular dysfunction caused by intracoronary adriamycin. Annal Thoracic Surgery. (1992) 53:861-3. doi: 10.1016/0003-4975(92)91452-F 
63. Toyoda Y, Okada M, Kashem MA. A canine model of dilated cardiomyopathy induced by repetitive intracoronary doxorubicin administration. J Thorac Cardiovasc Surg. (1998) 115:1367-73. doi: 10.1016/S0022-5223(98)70221-1

64. Goetzenich A, Hatam N, Zernecke A, Weber C, Czarnotta T, Autschbach $\mathrm{R}$, et al. Alteration of matrix metalloproteinases in selective left ventricular adriamycin-induced cardiomyopathy in the pig. J Heart Lung Transplant. (2009) 28:1087-93. doi: 10.1016/j.healun.2009.06.025

65. Carbone A, Psaltis PJ, Nelson AJ, Metcalf R, Richardson JD, Weightman $\mathrm{M}$, et al. Dietary omega-3 supplementation exacerbates left ventricular dysfunction in an ovine model of anthracycline-induced cardiotoxicity. J Card Fail. (2012) 18:502-11. doi: 10.1016/j.cardfail.2012.03.005

66. Wilson JR, Douglas P, Hickey WF, Lanoce V, Ferraro N, Muhammad A, et al. Experimental congestive heart failure produced by rapid ventricular pacing in the dog: cardiac effects. Circulation. (1987) 75:857-67. doi: 10.1161/01.CIR.75.4.857

67. Shinbane JS, Wood MA, Jensen DN, Ellenbogen KA, Fitzpatrick AP, Scheinman MM. Tachycardia-induced cardiomyopathy: a review of animal models and clinical studies. J Am Coll Cardiol. (1997) 29:709-15. doi: 10.1016/S0735-1097(96)00592-X

68. Möllmann H, Voss S, Nef HM, Lintz M, Oltenau C, Kostin S, et al. Desynchronization: a novel model to induce heart failure. Thorac Cardiovasc Surg. (2009) 57:441-8. doi: 10.1055/s-0029-1186070

69. Paslawska U, Kiczak L, Bania J, Paslawski R, Janiszewski A, Dziegiel P, et al. Inducible NO synthase is constitutively expressed in porcine myocardium and its level decreases along with tachycardia-induced heart failure. Cardiovasc Pathol. (2016) 25:3-11. doi: 10.1016/j.carpath.2015.08.003

70. Spinale FG, Tomita M, Zellner JL, Cook JC, Crawford FA, Zile MR. Collagen remodeling and changes in LV function during development and recovery from supraventricular tachycardia. Am J Physiol. (1991) 261(2 Pt 2):H308-18. doi: 10.1152/ajpheart.1991.261.2.H308

71. McMahon WS, Mukherjee R, Gillette PC, Crawford FA, Spinale FG. Right and left ventricular geometry and myocyte contractile processes with dilated cardiomyopathy: myocyte growth and beta-adrenergic responsiveness. Cardiovasc Res. (1996) 31:314-23. doi: 10.1016/S0008-6363(95)00212-X
72. Paslawska U, Gajek J, Kiczak L, Noszczyk-Nowak A, Skrzypczak P, Bania J, et al. Development of porcine model of chronic tachycardia-induced cardiomyopathy. Int J Cardiol. (2011) 153:36-41. doi: 10.1016/j.ijcard.2010.08.033

73. Malinowski M, Proudfoot AG, Langholz D, Eberhart L, Brown M, Schubert $\mathrm{H}$, et al. Large animal model of functional tricuspid regurgitation in pacing induced end-stage heart failure. Interact Cardiovasc Thorac Surg. (2017) 24:905-910. doi: 10.1093/icvts/ivx012

74. Singal PK, Iliskovic N. Doxorubicin-induced cardiomyopathy. N Engl J Med. (1998) 339:900-5. doi: 10.1056/NEJM199809243391307

75. Perreault CL, Shannon RP, Komamura K, Vatner SF, Morgan JP. Abnormalities in intracellular calcium regulation and contractile function in myocardium from dogs with pacing-induced heart failure. J Clin Invest. (1992) 89:932-8. doi: 10.1172/JCI115674

76. Dixon JA, Spinale FG. Large Animal Models of Heart Failure. Circulat. Heart Fail. (2009) 2:262-71. doi: 10.1161/CIRCHEARTFAILURE.108.814459

77. Camacho P, Fan H, Liu Z, He JQ. Large Mammalian Animal Models of Heart Disease. J Cardiovas Develop Dis. (2016) 3:30. doi: 10.3390/jcdd3040030

78. Houser SR, Margulies KB, Murphy AM, Spinale FG, Francis GS, Prabhu SD, et al. Animal models of heart failure. Circulat Res. (2012) 111:131-50. doi: 10.1161/RES.0b013e3182582523

Conflict of Interest Statement: The authors declare that the research was conducted in the absence of any commercial or financial relationships that could be construed as a potential conflict of interest.

Copyright (C) 2019 Spannbauer, Traxler, Zlabinger, Gugerell, Winkler, MesterTonczar, Lukovic, Müller, Riesenhuber, Pavo and Gyöngyösi. This is an open-access article distributed under the terms of the Creative Commons Attribution License (CC $B Y)$. The use, distribution or reproduction in other forums is permitted, provided the original author(s) and the copyright owner(s) are credited and that the original publication in this journal is cited, in accordance with accepted academic practice. No use, distribution or reproduction is permitted which does not comply with these terms. 